\title{
Global Supply Chain Management: Is Sustainability A Priority?
}

Linda C. Ueltschy, Bowling Green State University, USA

\begin{abstract}
Agrigalore $^{1}$ is an international agribusiness headquartered in the U. S. Midwest. Increased competition in the soybean sector has spurred Agrigalore to consider producing in Brazil, yet concerns over destruction of the rainforest and sustainability need to be factored into management's decision.
\end{abstract}

Keywords: supply chain; sustainability; Brazil

\section{INTRODUCTION}

grigalore is an international producer and marketer of food and agricultural products headquartered in the Midwest of the United States, having been in business for more than a hundred years. Agrigalore is committed to helping customers succeed through collaboration and innovation, sharing its knowledge and experience to help meet economic, environmental and social challenges.

In the area of agriculture, Agrigalore produces, buys, processes and distributes grain and other commodities to makers of food and animal nutrition products, as well as provides products to crop and livestock producers. In the food sector, Agrigalore supplies high-quality ingredients to food and beverage manufactures.

Agrigalore has enjoyed increases in sales and profits for the past seven years with over $\$ 35$ billion in sales and revenues in the fiscal year 2010. However, one area where increased competition is starting to take its toll is in the soybean sector. Although the United States is still projected to be the world leader in soybean production for 2009-2010 at 88.2 million tons (Ashbridge, 2010), Brazil is gaining ground in the world market, as is Argentina.

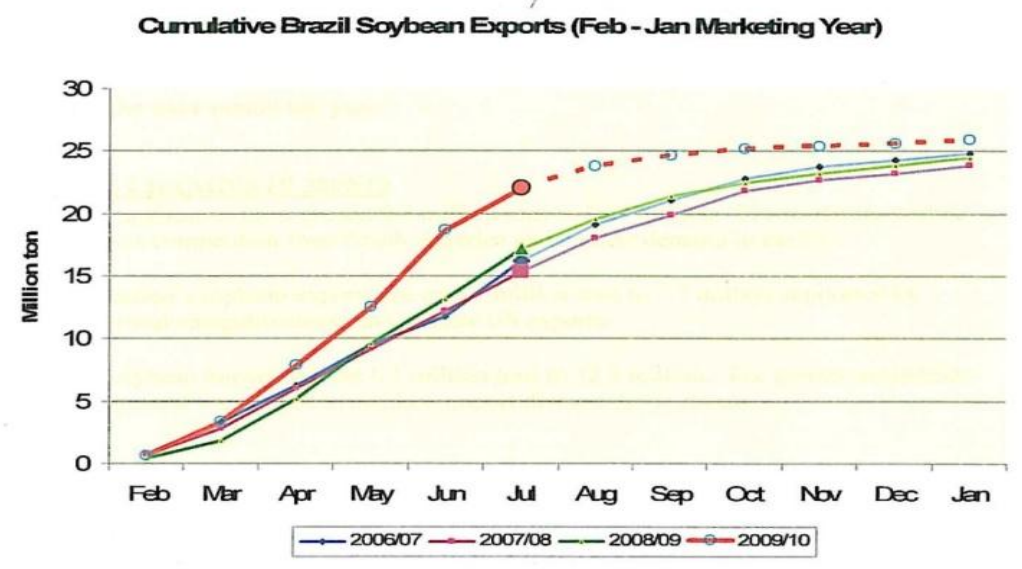

Figure 1

(United States Department of Agriculture, 2009)

\footnotetext{
${ }^{1}$ company and characters are fictitious
} 
The trend has had its effect on the market share held by Agrigalore in the soybean market. Agrigalore is considering whether it should acquire land and begin producing in Brazil itself, which would give it more access to the large Brazilian market, as well as enable it to produce in a climate which can grow two soybean crops per year.

John Xavier, V.P. of Global Supply Chain Operations, has been asked to prepare his suggestions to be discussed at the executive team meeting next month. He is sitting down to examine the market and the opportunities and challenges of producing in Brazil in order to decide the best way for Agrigalore to grow and protect its market share in the soybean industry.

\section{WORLD SOYBEAN MARKET}

Thanks to China's soaring demand for soya products, soybeans are the most imported agricultural commodity in the world in terms of value and quantity" (Workman, 2007, p.1). Soybean production worldwide, according to the 2009-2010 projection, is expected to total 247.2 million tons. Of this, the United States remains the leading producer with 88.2 million tons expected, but Brazil and Argentina are gaining ground. Brazil's soybean production is expected to be 62 million tons and Argentina's at 52 million tons, which is a significant increase over the 26 million tons produced in 2009 (Ashbridge, 2010). The majority of the soybean exports went to China, the largest consuming nation at 2 billion bushels this year; this equates to 60 percent of the entire U.S. crop.

\section{SOYBEAN PRODUCTION IN BRAZIL}

There has been an increased domestic demand for soybeans, which has limited, to a certain extent, the amount of soybeans available for exports. Nonetheless, Brazil's average annual growth rate of soybean production over the past four decades is 14 percent average annual increase, compared to 5 percent annual growth rate in the U.S. over the same time period. Additionally, droughts in Argentina and Paraguay have helped shift market share to Brazil (Oilseeds, 2009). Industry experts expect Brazil to overtake the United States as the world's largest soybean producer within the next five years. As of 2005 , it had already overtaken the U.S. as the world's largest soybean exporter, with China being its top export destination (Workman, 2007).

\section{“GREEN" RESPONSE TO INCREASED SOYBEAN PRODUCTION IN BRAZIL}

Between June, 2000 and June, 2008, more than 150,000 square kilometers of rainforest were cleared in the Brazilian Amazon. The reasons for this can, in part, be traced to drastic changes in Brazil's agriculture over the past three decades. Population growth and increased demand for food and bio-fuels have expanded the boundaries of planted land. Additionally, surging demand from China and other emerging economies has caused a worldwide boom over the last few years, which has helped trigger a land rush that precipitated the conversion of natural forest for farms, plantations, and ranches (mongabay.com, 2009), this has resulted in escalating real estate values. International environmental groups, such as Greenpeace, are lobbying against possible infrastructure improvements, which they view will promote deforestation in an ecologically-sensitive area. Rainforests are home to as many as two-thirds of all living species and the Amazon rainforest is considered one of the world's richest collections of biological diversity. In response to pressure from environmental groups like Greenpeace, the Brazilian soy industry has agreed to extend a moratorium on soy production in newly deforested areas in the rainforest which began in 2006 (mongabay.com, 2009).

\section{ACTIONS OF THE BRAZILIAN GOVERNMENT}

Brazil, by far the largest country in area in Latin America, and also the most populous, with 204 million residents, has achieved high economic growth. Even in the current global recession, Brazil's GDP is expected to grow 4.5 percent (World Fact Book, 2010). Nonetheless, a problem facing Brazil is very uneven distribution of population and wealth. Brazil is said to have the greatest disparity between rich and poor in the world. Some of the poor live in "favelas," or poor sections of metropolitan areas, but many are indigenous people or subsistence farmers who live in the country's Northeast and Northern regions and that continue to migrate in large numbers to the highly populated cities. In fact, the vast majority of Brazilians live in cities located within $600 \mathrm{kms}$ of the Atlantic shore, with 45 percent living in just three Southeastern states: São Paulo, Rio de Janeiro and Minas Gerais. 
In an effort to develop more of its country, feed its people and help its poor, the Brazilian government has taken several actions. In 1956, it built a planned city, Brasilia, which became the official national capital in 1960. The leaders of Brazil believed that by relocating the capital, congestion in Rio de Janeiro would be alleviated and the new capital would promote development in the then unpopulated Cerrado (Tropical Savanna). The master plan for Brasilia was to have approximately 800,000 inhabitants, so its population of 2.6 million in 2010 far exceeds the goal. However, the Southeastern states on the Atlantic Coast remain more crowded than ever.

A program to improve social and productive integration for western Amazonia is the Free Trade Zone or Zona Franca de Manaus. It has attracted more than 600 companies, including many of the world's largest enterprises. However, the lack of paved roads connecting it to the east, west or south of the country remains a problem and one of the main constraints inhibiting greater expansion of the FTZ of Manaus.

Congressional initiatives in Brazil have encouraged poor farmers to settle on forest lands. In Brazil, each squatter acquires the right to continue using a piece of land by living on it and "using it" for at least one year and a day. After five years, the squatter acquires title to the land and can even sell it. Up until the mid-1990's, the government allowed the squatter to gain title to an amount of land up to three times the amount of forest cleared. Between 1995 and 1998, the government granted land in the Amazon to approximately 150,000 families. In June, 2009, Brazilian President Lula signed a law granting 67.4 hectares of land in the rainforest to more than 1 million illegal settlers (Butler, 2009). Thus, these actions have helped to engage more Brazilian citizens in agriculture, which helps to feed the poor and the nation, and to develop more of the country, but has also contributed to more deforestation of the Amazon jungle.

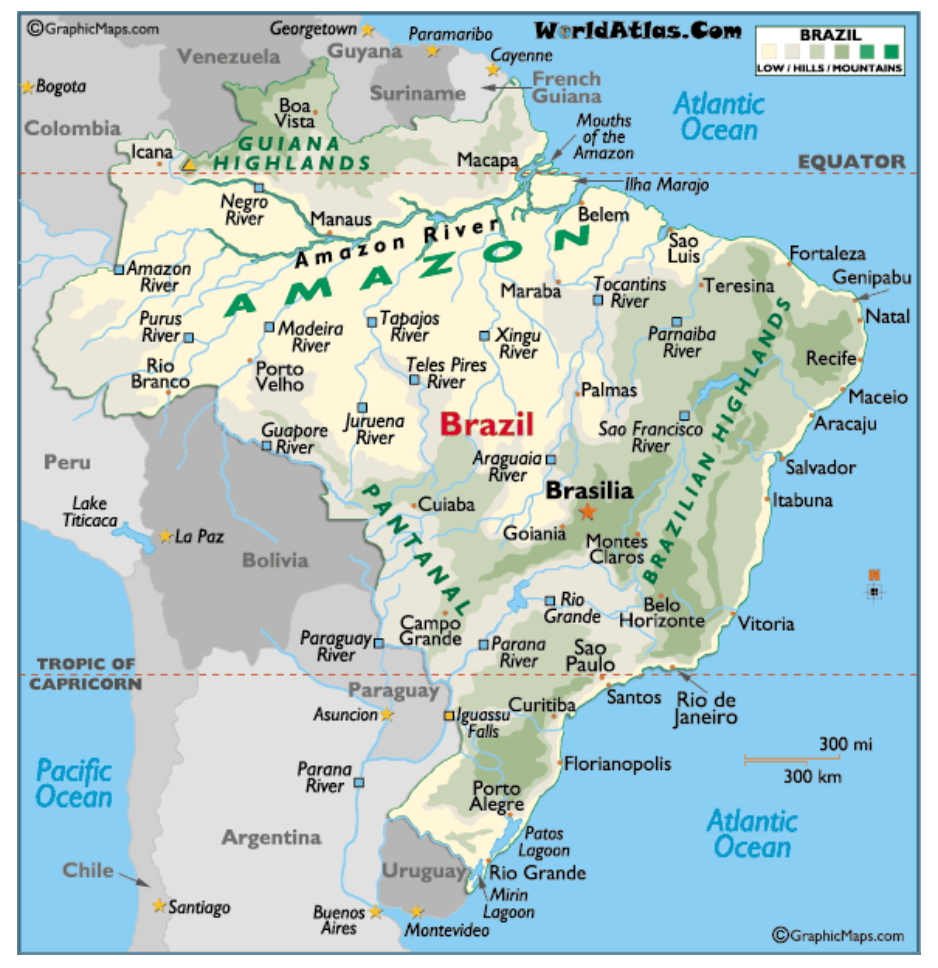

Figure 2: Map of Brazil

An interesting phenomenon is that Brazilian deforestation is positively correlated to the economic health of the country (Butler, 2009); when pasturelands are expanded and more land devoted to agricultures, growth in the GDP occurs and exports increase. According to environmentalists, favorable taxation policies enacted by the 
government, combined with the government subsidized agriculture, encourage the destruction of the rainforest. Their contention is that low taxes on income derived from agriculture and low tax rates on pastureland makes deforestation profitable. However, Brazil still accounts for 74 percent of land protected globally in conservation areas established since 2003, according to a study published in Biological Conservation (2009). Additionally, Brazil started paying small farmers \$50/month in 2009 to plant trees in deforested parts of the Amazon. Last, responding to allegations that major Brazilian cattle producers are responsible for illegal clearing of the Amazon rainforest, Brazil's Development Bank, as of 2009, now requires producers to trace the origin of the beef back to the ranch where it was produced to ensure that the beef did not come from illegally forested land. Thus, the Brazilian government has tried to balance its actions in terms of need for economic growth and environmental concerns.

\section{INFRASTRUCTURE NEEDS AND CHALLENGES}

Brazilian infrastructure projects may require as much as $\$ 85$ billion in financing over the next decade, which is luring investors, foreign and domestic, as the country prepares for the World Cup in 2014 and the Olympics in 2016 (Moura, 2010). Brazil will become the fifth nation to host the World Cup twice and will be home to the first World Cup held in South America since 1978. In addition to stadium upgrades, millions will be spent on basic infrastructure needs such as highways, subways and railroads to get the country ready to accommodate and transport guests. This will also be true of infrastructure needs pertaining to the 2016 Olympics in Rio de Janeiro.

Perhaps the fact that Manaus is one of 12 host cities for the 2016 Olympics in Brazil will be an impetus for infrastructure improvement in the Amazon, an area in dire need of upgrades to the highway system. Roads, specifically paved roads, are needed to provide access to logging and mining sites, to allow farmers to bring their products to market, and to enable those living in the Amazon region to be able to receive needed products and services and to travel to other parts of the country. More paved highways are particularly critical as a means of gathering production from the farms for processing in facilities located in river ports or near railway terminals.

One of the most ambitious infrastructure plans was in the 1970's when Brazil planned the TransAmazonian Highway, also known as BR-230, a 2000-mile highway that would bisect the Amazon forest, opening lands to peasants, and the development of its timber and mineral resources to maintain economic growth. However, this highway was plagued from the start with the sediments of the Amazon, rendering the highway unstable and subject to floods, so its positive impact was minimized, giving the environmentalists ammunition to use in their arguments. More recently, the discussion has turned to another highway in the Amazon, BR-163. BR-163 was originally built between 1973 and 1974 and is unpaved in large part and often impassable. In 2000, plans to pave BR-163 surfaced as a means to provide an effective route for transport of products and people. Immediately, the international environmental groups rallied their forces to block its paving, saying it would cause more fires in the rain forest and signal disaster in the Amazon due to the development it would enable. The Brazilian government spent money to start paving BR-163, but yielded to the pressure of the environmental groups and agreed to only clear enough of the rainforest to actually build the highway. Unfortunately, this led to the demise of the paving of BR-163. By the time the highway was not even halfway paved, the rainforest had already buried the paved portion.

BR-163 is still not paved, and largely impassible, as well as many other roads in the rainforest. However, a new push is underway to provide a viable export corridor for soybeans from the rainforests. Reconstructing the highway is part of an evolving series of plans for massive infrastructure expansion. The governor of Mato Grosso since 2003 is Brazil's largest soybean producer and a major force in inducing the federal government to pave the road. With the paving of BR-163, soybeans would only have to travel half the current distance to reach the port of Paranguá, even though it is a very congested port. Historically soybeans have been produced in the Southern region of Brazil, but the expansion of the agricultural frontier to the Central-West region has created the need for a second export corridor using the waterway network of the Amazon region and the port of Santarem, although Greenpeace strongly opposes this.

In relation to other areas of infrastructure, Brazil has $28,857 \mathrm{~km}$ of railways, which ranks tenth in the world. Having 50,000 km of waterways puts Brazil in third place in the world in terms of usable waterways, with seven world class ports in strategic locations to its credit. Brazil has an excellent telecommunication system, ranking fifth in the world in cell phone usage and sixth in terms of land lines available. It has an extensive 
microwave radio relay system and an impressive domestic satellite system. It ranks fifth in the world both in terms of internet hosts and internet usage, with growth noted in both (Brazil: World Factbook, 2010). Brazil offers excellent storage facilities, but grain storage facilities are in short supply. Brazilian agribusiness officials are worried that Brazil is running out of soybean storage and that this problem could be a chronic obstacle to further expansion and growth (Rocher and Campos, 2010).

\section{CONSIDERATIONS FOR JOHN XAVIER}

1. Should Agrigalore try to acquire land in Brazil to take advantage of the favorable climate which allows two crops per year? Should Agrigalore try to partner with an existing Brazilian soybean producer in a joint venture? Should Agrigalore try to buy out an existing Brazilian soybean producer? What are the pros and cons of each entry mode?

2. What should John consider regarding distribution decisions related to each entry mode? What trade-offs would need to be evaluated? What costs should be considered in the design of Agrigalore's Brazilian distribution network (i.e., environmental costs, investment costs, costs to reputation)?

3. What possible role will the Brazilian government have in Agrigalore's success or failure if it decides to produce in Brazil?

4. Are there ethical considerations to be considered? Do the arguments of the international environmental groups have any validity? Since Agrigalore tries to share its knowledge and experience to meet economic, environmental and social challenges, how does this play into its business decision? Would its entry into Brazil help the economic growth of the country and improve the lives of the poor farmers? Are the environmental issues surrounding the rainforest so crucial that Agrigalore should not consider producing in Brazil? Are there ways Agrigalore could support sustainability and still produce in Brazil?

5. Should international organizations have any say in Brazil's decisions as to how it develops its country? Are there any international organizations that have enough power to pressure or force their ideas on Brazil? What kind of power would enable them to do this?

What should John Xavier's recommendations be to the executive team and why? ${ }^{2}$

\section{ACKNOWLEDGEMENT}

Humberto Flores, Damco Corporation, President for Latin America, contributed insights for this case.

\section{AUTHOR INFORMATION}

Dr. Linda C. Ueltschy, a 2009 Fulbright scholar, is an Associate Professor of International Business at Bowling Green State University in Ohio. Having conducted international marketing research in over 30 countries, her research focuses on how culture impacts customer satisfaction, advertising preferences, co-branding, perceived risk of online purchasing, and supply chain relationships. Her research articles have appeared in numerous journals including the Journal of International Marketing, Journal of Business Research, Journal of Services Marketing and Journal of Applied Business Research, to name a few. E-mail: ueltsch@bgsu.edu

\section{REFERENCES}

1. Ashbridge, David (2010), "South America, China Influence Late Winter Markets," United Soybean Board Export Advice (February 23).

2. "Brazil to Boost Spending on Infrastructure to Counter Economic Crisis," (2009), www.mongabay.com (February 5).

3. Brazil: World Factbook (2010), Central Intelligence Agency, www.cia.gov/library

4. Butler, Rhett A. (2009), "Deforestation in the Amazon," www.mongabay.com/brazil.

5. "Early Surge in Brazil's Soybean Exports Cannibalizes Late Season Sales," (2009), Oilseeds: World Markets and Trade, (August), United States Department of Agriculture.

6. Freivalds, John (2009), “Amazon Road: Travel BR-163 Thought the Rainforest,” brazilmax.com (August 
26).

7. Moura, Fabiola (2010), "Brazil Infrastructure Projects Require \$85 Billion in Financing," Business Week, (March 7).

8. Rocher, José and Jonathan Campos (2010), "Running Out of Soybean Storage in Brazil," Gazeta do Povo (April 19), www.agriculture.com

9. Workman, Daniel (2007), "Top Soybean Countries: America, Brazil and Argentina Lead Exporters to Largest Importer China," www.internationaltrade.suite101.com, (Sept. 17).

\footnotetext{
${ }^{2}$ This case could be used innovatively by engaging two undergraduate classes, one from the U.S. and one from another Englishspeaking country, such as Canada, Australia, U.K., in a discussion and debate using video-conferencing technology. If desired, one class might take the role of environmentalists and the other the role of Brazilian soybean farmers, loggers or just citizens living in Brasilia.
} 